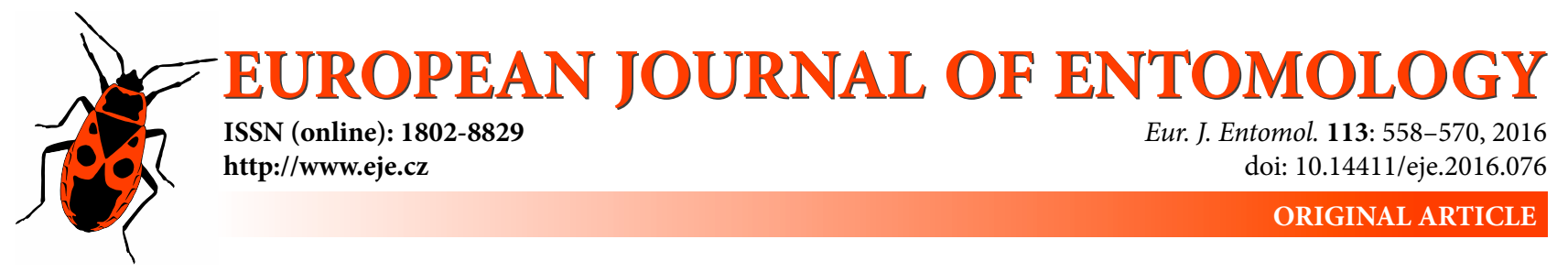

\title{
Characterization of the complete mitochondrial genome of Spilarctia robusta (Lepidoptera: Noctuoidea: Erebidae) and its phylogenetic implications
}

\author{
Yu Sun, Sen tian, Cen QIAN, Yu-Xuan Sun, Muhammad N. AbBas, Saima KaUSAR, Lei Wang, Guoqing Wei, \\ BAO-JIAN ZHU* and CHAO-LIANG LIU* \\ College of Life Sciences, Anhui Agricultural University, 130 Changjiang West Road, Hefei, 230036, China; \\ e-mails: nagato0621@163.com (Y. Sun), 471618348@qq.com (S.Tian), qiancenqiancen@163.com (C. Qian), \\ sun6667@163.com (Y.-X. Sun), abbasmndr@outlook.com (M.-N. Abbas), drkausarsn@hotmail.com (S. Kausar), \\ wanglei20041225@163.com (L. Wang), weiguoqing@tom.com (G.-Q. Wei), zhubaojian@ahau.edu.cn (B.-J. Zhu), \\ clliu@ahau.edu.cn (C.-L. Liu)
}

Key words. Lepidoptera, Noctuoidea, Erebidae, Spilarctia robusta, phylogenetic analyses, mitogenome, evolution, gene rearrangement

\begin{abstract}
The complete mitochondrial genome (mitogenome) of Spilarctia robusta (Lepidoptera: Noctuoidea: Erebidae) was sequenced and analyzed. The circular mitogenome is made up of 15,447 base pairs (bp). It contains a set of 37 genes, with the gene complement and order similar to that of other lepidopterans. The 12 protein coding genes (PCGs) have a typical mitochondrial start codon (ATN codons), whereas cytochrome c oxidase subunit 1 (cox1) gene utilizes unusually the CAG codon as documented for other lepidopteran mitogenomes. Four of the 13 PCGs have incomplete termination codons, the cox 1 , nad 4 and nad 6 with a single T, but cox 2 has TA. It comprises six major intergenic spacers, with the exception of the A+T-rich region, spanning at least 10 bp in the mitogenome. The nucleotide composition of the genome is greatly A+T biased (81.09\%), with a negative AT skewness $(-0.007)$, indicating the presence of fewer As than Ts, similar to other Noctuoidea. The A+T-rich region is 343 bp long, and contains some conserved regions, including an "ATAGA" motif followed by a 19 bp poly-T stretch, a microsatellite-like (AT), and a poly-A element, a characteristic shared with other lepidopteran mitogenomes. Phylogenetic analysis, based on 13 PCGs using Maximum likelihood methods revealed that $S$. robusta belongs to the superfamily Noctuoidea.
\end{abstract}

\section{INTRODUCTION}

The insect mitochondrial genome is a circular molecule, ranging in size from 15 to $19 \mathrm{~kb}$ (Jiang et al., 2009). It contains a set of 37 genes that are typically similar in all insects sequenced to date. On the basis of their physiological functions, they are divided into 13 protein coding (two ATPase genes [atp6 and atp8], seven NADH dehydrogenase [nad1-nad6 and nad4L], a cytochrome $\mathrm{b}$ [cob], three cytochrome c oxidase [cox1-cox3]), 22 transfer RNAs and two ribosomal RNAs ( $r r n L$ and $r r n S$ ) genes (Shadel \& Clayton, 1993; Cameron, 2014). In addition, it has a control region of variable length (A+T-rich region) (Wolstenholme, 1992). The mitochondrial DNA (mtDNA) is extremely conserved and is maternally inherited. Moreover, it is non-recombinant and undergoes reductive evolution. Therefore, the study of the mitogenome is considered to be important for understanding molecular evolution, comparative and evolutionary genomics, phylogenetics and population genetics (Boore, 1999; Babbucci et al., 2014; Cameron, 2014).

Lepidoptera (moths and butterflies) is the second largest order in the class Insecta, containing greater than 155,000 described species that are classified into 45-48 superfamilies. Noctuoidea is a highly diverse superfamily, with approximately 42,400 species distributed worldwide (Hao et al., 2012; Zhang, 2013). Despite, this enormous taxonomic diversity, knowledge on the mitochondrial genome (mitogenome) of the Noctuoidea is uneven (Table 1). In particular, information is scanty on six families (Oenosandridae, Notodontidae, Erebidae, Euteliidae, Nolidae and Noctuidae) of Noctuoidea, and interestingly only a few lineages support the relationship of Erebidae (Zahiri et al., 2012). Arctiinae upgraded to family from Erebidae (Lafontaine $\&$ Fibiger, 2006) has been recently revised by Zahiri et al. (2011). Moreover, it also has a complex evolutionary relationship with plant and fungal chemistry (Zaspel et al.,

\footnotetext{
* Corresponding authors; e-mails: zhubaojian@ahau.edu.cn (B.-J. Zhu), clliu@ahau.edu.cn (C.-L. Liu).
} 
Table 1. Details of the lepidopteran mitogenomes used in this study.

\begin{tabular}{|c|c|c|c|c|c|}
\hline Superfamily & Family & Species & Size (bp) & GenBank accession no. & Reference \\
\hline Bombycoidea & Sphingidae & $\begin{array}{l}\text { Bombyx mandarina } \\
\text { Bombyx mori } \\
\text { Actias selene } \\
\text { Antheraea pernyi } \\
\text { Antheraea yamamai } \\
\text { Manduca sexta } \\
\text { Sphinx morio }\end{array}$ & $\begin{array}{l}15,682 \\
15,643 \\
15,236 \\
15,566 \\
15,338 \\
15,516 \\
15,299\end{array}$ & $\begin{array}{l}\text { NC_003395 } \\
\text { NC_002355 } \\
\text { NC_018133 } \\
\text { AY242996 } \\
\text { NC_012739 } \\
\text { NC_010266 } \\
\text { NC_020780.1 }\end{array}$ & $\begin{array}{l}\text { Yukuhiro et al., } 2002 \\
\text { direct submission } \\
\text { Liu et al., } 2012 \\
\text { Liu et al., } 2008 \\
\text { Kim et al., 2009b } \\
\text { Cameron \& Whiting, } 2008 \\
\text { Kim et al., } 2013\end{array}$ \\
\hline Noctuoidea & $\begin{array}{l}\text { Lymantriidae } \\
\text { Erebidae }\end{array}$ & $\begin{array}{l}\text { Lymantria dispar } \\
\text { Spilarctia robusta } \\
\text { Lemyra melli } \\
\text { Amata formosae } \\
\text { Hyphantria cunea }\end{array}$ & $\begin{array}{l}15,569 \\
15,447 \\
15,418 \\
15,463 \\
15,481\end{array}$ & $\begin{array}{l}\text { NC } 012893 \\
\text { KX } 753670 \\
\text { NC_026692 } \\
\text { KC513737 } \\
\text { NC } 014058\end{array}$ & $\begin{array}{l}\text { unpublished } \\
\text { present study } \\
\text { unpublished } \\
\text { Lu et al., } 2013 \\
\text { Liao et al., } 2010\end{array}$ \\
\hline & Notodontidae & $\begin{array}{l}\text { Phalera flavescens } \\
\text { Ochrogaster lunifer }\end{array}$ & $\begin{array}{l}15,659 \\
15,593\end{array}$ & $\begin{array}{l}\text { NC_016067 } \\
\text { NC_011128 }\end{array}$ & $\begin{array}{l}\text { Sun et al., } 2012 \\
\text { Salvato et al., } 2008\end{array}$ \\
\hline & Nolidae & $\begin{array}{l}\text { Agrotis ipsilon } \\
\text { Eutelia adulatricoides } \\
\text { Mythimna separata } \\
\text { Gabala argentata }\end{array}$ & $\begin{array}{l}15,377 \\
15,360 \\
15,329 \\
15,337\end{array}$ & $\begin{array}{l}\text { KF163965 } \\
\text { KJ185131 } \\
\text { KM099034.1 } \\
\text { KJ410747 }\end{array}$ & $\begin{array}{l}\text { Wu et al., } 2015 \\
\text { Yang et al., } 2015 \\
\text { Liu et al., } 2015 \\
\text { Yang et al., } 2015\end{array}$ \\
\hline Geometroidea & Geometridae & $\begin{array}{l}\text { Apocheima cinerarium } \\
\text { Biston panterinaria } \\
\text { Phthonandria atrilineata } \\
\text { Biston thibetaria } \\
\text { Biston suppressaria } \\
\text { Jankowskia athleta }\end{array}$ & $\begin{array}{l}15,722 \\
15,517 \\
15,499 \\
15,484 \\
15,628 \\
15,534\end{array}$ & $\begin{array}{l}\text { KF836545 } \\
\text { NC_020004 } \\
\text { NC_010522 } \\
\text { KJ670146.1 } \\
\text { KP278206 } \\
\text { KR822683 }\end{array}$ & $\begin{array}{l}\text { Liu et al., } 2014 \\
\text { Yang et al., } 2013 \\
\text { Yang et al., } 2009 \\
\text { unpublished } \\
\text { Chen et al., } 2016 \\
\text { Xu et al., } 2015\end{array}$ \\
\hline Pyraloidea & $\begin{array}{l}\text { Crambidae } \\
\text { Pyralidae }\end{array}$ & $\begin{array}{l}\text { Chilo suppressalis } \\
\text { Diatraea saccharalis } \\
\text { Ephestia kuehniella }\end{array}$ & $\begin{array}{l}15,395 \\
15,490 \\
15,327\end{array}$ & $\begin{array}{l}\text { NC_015612 } \\
\text { NC-013274 } \\
\text { KE } 3058322\end{array}$ & $\begin{array}{l}\text { Chai et al., } 2012 \\
\text { Li et al., } 2011\end{array}$ \\
\hline Tortricoidea & Tortricidae & $\begin{array}{l}\text { Spilonota lechriaspis } \\
\text { Grapholita molesta }\end{array}$ & $\begin{array}{l}15,368 \\
15,717\end{array}$ & $\begin{array}{l}\text { NC_014294 } \\
\text { NC_014806 }\end{array}$ & $\begin{array}{l}\text { Zhao et al., } 2011 \\
\text { Gong et al., } 2012\end{array}$ \\
\hline Papilionoidea & Nymphalidae & $\begin{array}{l}\text { Parnassius bremeri } \\
\text { Papilio maraho } \\
\text { Teinopalpus aureus } \\
\text { Apatura ilia } \\
\text { Apatura metis } \\
\text { Fabriciana nerippe } \\
\text { Argynnis hyperbius }\end{array}$ & $\begin{array}{l}15,389 \\
16,094 \\
15,242 \\
15,242 \\
15,236 \\
15,140 \\
15,156\end{array}$ & $\begin{array}{l}\text { NC_014053 } \\
\text { NC_014055 } \\
\text { NC_014398 } \\
\text { NC-016062 } \\
\text { NC-015537 } \\
\text { NC-016419 } \\
\text { NC-015988 }\end{array}$ & $\begin{array}{l}\text { Kim et al., 2009a } \\
\text { Wu et al., } 2010 \\
\text { unpublished } \\
\text { Chen et al., } 2012 \\
\text { Zhang et al., } 2012 \\
\text { Kim et al., } 2011 \\
\text { Kim et al., } 2011\end{array}$ \\
\hline $\begin{array}{l}\text { Yponomeutoidea } \\
\text { Hepialoidea }\end{array}$ & $\begin{array}{l}\text { Plutellidae } \\
\text { Lyonetiidae } \\
\text { Hepialidae }\end{array}$ & $\begin{array}{l}\text { Plutella xylostella } \\
\text { Leucoptera malifoliella } \\
\text { Thitarodes renzhiensis } \\
\text { Ahamus yunnanensis }\end{array}$ & $\begin{array}{l}16,179 \\
15,646 \\
16,173 \\
15,816 \\
\end{array}$ & $\begin{array}{l}\text { JF911819 } \\
\text { NC_018547 } \\
\text { NC_018094 } \\
\text { NC_018095 }\end{array}$ & $\begin{array}{l}\text { Wei et al., } 2013 \\
\text { Wu et al., } 2012 \\
\text { Cao et al., } 2012 \\
\text { Cao et al., } 2012\end{array}$ \\
\hline
\end{tabular}

2014). Therefore, this taxonomic group has attracted the attention of researchers all over the world, and their main focus is to establish relationships within the group as well as with other taxonomic categories.

Spilarctia robusta (Lepidoptera: Noctuoidea: Erebidae: Arctiinae) is a major arthropod pest of trees. This species largely infests forests, but also damages roadside and garden trees in urban areas. The economic losses are increasing at an alarming rate (Liao et al., 2010). Therefore, considering its economic importance as well as the lack of information on its evolutionary relationships, we designed the present study, in order to sequence and annotate the complete mitogenome of S. robusta. Moreover, we compared it with other Lepidoptera that have been sequenced in order to highlight their evolution, particularly the phylogenetic relationships of Noctuoidea and Erebidae.

\section{MATERIALS AND METHODS}

\section{Experimental insects and DNA extraction}

Spilarctia robusta (moth) specimens were collected from Anhui Agricultural University (AHAU), Anhui Province, China. These specimens were identified as $S$. robusta by a taxonomist (Department of Entomology, AHAU). Total DNA was extracted using a Genomic DNA Extraction Kit (Aidlab Co., Beijing, China) according to the manufacturer's instructions.

\section{PCR amplification, cloning and sequencing}

We designed twelve pairs of primers from the conserved nucleotide sequences of known mitochondrial genomes of Lepidoptera to determine the sequence characteristics of the $S$. robusta mitogenome (Liu et al., 2013; Dai et al., 2015). The complete list

Table 2. Details of the primers used to amplify the mitogenome of S. robusta.

\begin{tabular}{ll}
\hline Primer pair & \multicolumn{1}{c}{ Primer sequences ( 5'-3' ) } \\
\hline F1 & TAAAAATAAGCTAAATTTAAGCTT \\
R1 & TATTAAAATTGCAAATTTAAGGA \\
F2 & AAACTAATAATCTTCAAAATTAT \\
R2 & AAAATAATTTGTTCTATTAAAG \\
F3 & TGGAGCAGGAACAGGATGAAC \\
R3 & GAGACCADTACTTGCTTTCAG \\
F4 & ATTTGGGAGCTAATCATAG \\
R4 & GGTCAGGGACTATAATCTAC \\
F5 & TCGACCTGGAACTTTAGC \\
R5 & GCAGCTATAGCCGCTCCTACT \\
F6 & TAAGCTGCTAACTTAATTTTAGT \\
R6 & CCTGTTTCAGCTTTAGTTCATTC \\
F7 & CCTAATTGTCTTAAAGTAGATAA \\
R7 & TGCTTATTCTTCTGTAGCTCATAT \\
F8 & TAATGTATAATCTTCGTCTATGTAA \\
R8 & ATCAATAATCTCCAAAATTATTAT \\
F9 & ACTTTAAAAACTTCAAAGAAAAA \\
R9 & TCATAATAAATTCCTCGTCCAATAT \\
F10 & GGAGCTTCTACATGAGCTTTTGG \\
R10 & GTTTCGACCTCGATGTTG \\
F11 & GGTCCCTTACGATTTGAATATATCCT \\
R11 & AAACTAGGATTAGATACCCTATTAT \\
F12 & CTCTACTTTGTACGACTTATT \\
R12 & TCTAGGCCAATTCAACAACC \\
\hline
\end{tabular}




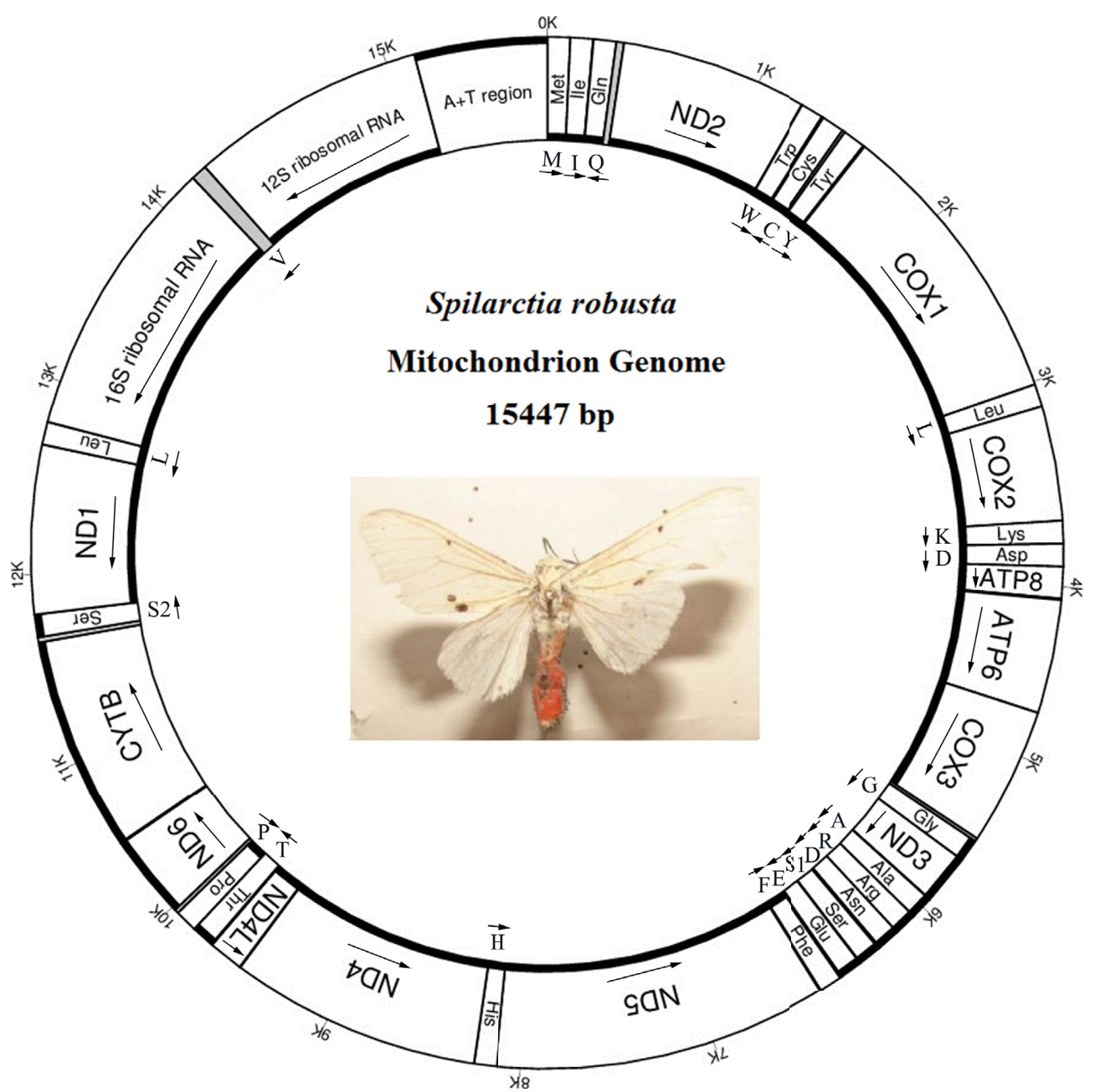

Fig. 1. Map of the mitogenome of $S$. robusta. The tRNA genes are labelled according to the IUPAC-IUB single-letter amino acids: cox1, cox2 and cox3 refer to the cytochrome c oxidase subunits; cob cytochrome b; nad1-nad6 NADH dehydrogenase components; rrnL and rrnS ribosomal RNAs. Genes named above the bar are located on major strands, while the others are located on minor strands.

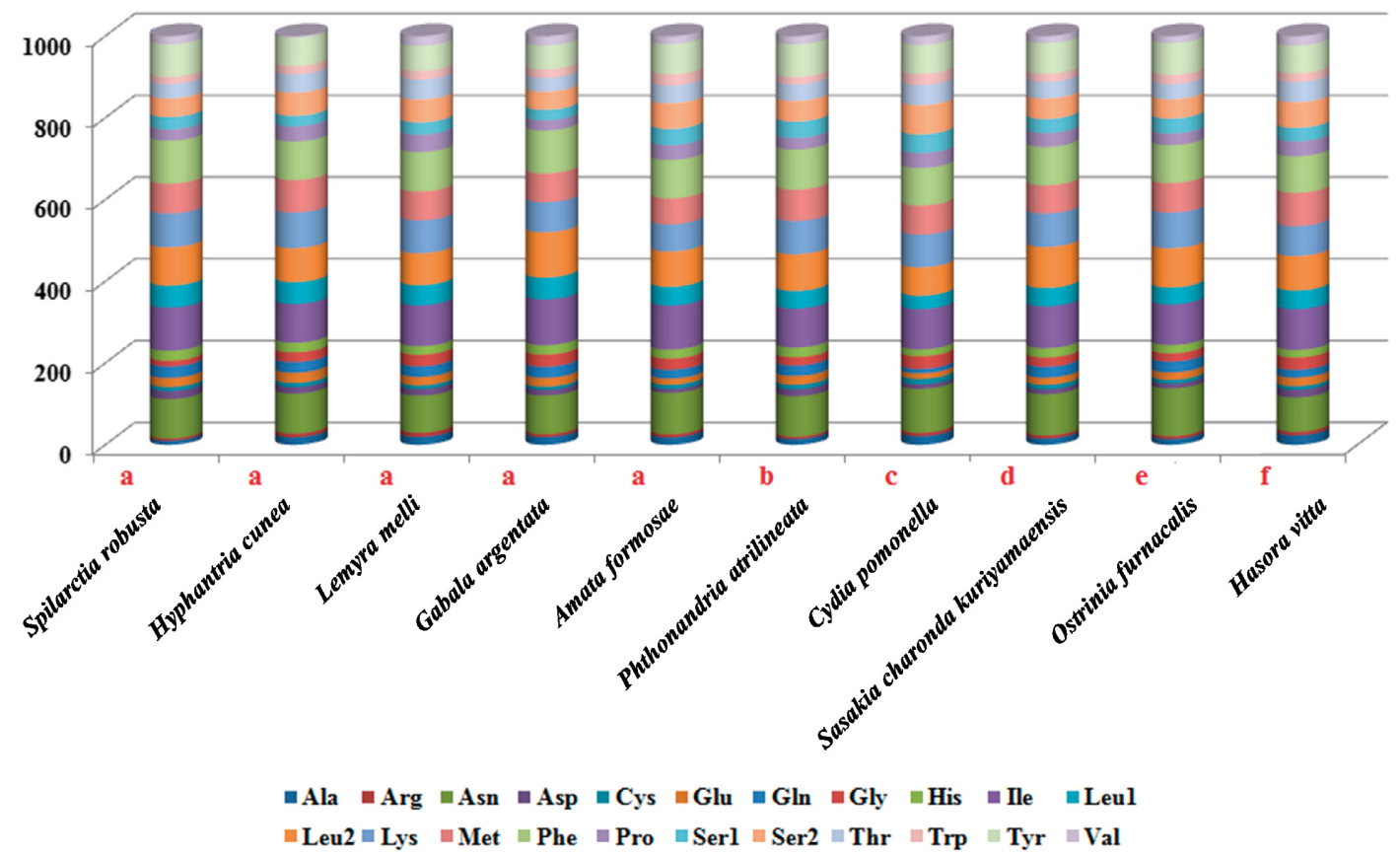

Fig. 2. Comparison of the size of each codon within the mitochondrial genome of different species of Lepidoptera. Lowercase letters (a, $b, c, d, e$ and f) above species name indicate the superfamily to which the species belong (a - Noctuoidea; $b-$ Geometroidea; $c$ - Tortricoidea, $d$ - Papilionoidea; e - Pyraloidea; $f$ - Hesperioidea). 
Table 3. List of the annotated mitochondrial genes of S. robusta.

\begin{tabular}{|c|c|c|c|c|c|c|c|c|}
\hline Gene & Product & Direction & Location & Size & Anti codon & Start codon & Stop codon & $\begin{array}{c}\text { Intergenic } \\
\text { Nucleotides }\end{array}$ \\
\hline $\operatorname{trnM}$ & $\mathrm{tRNA}^{\mathrm{Met}}$ & $\mathrm{F}$ & 1-67 & 67 & CAT & - & - & 0 \\
\hline trnl & tRNAlle & $\mathrm{F}$ & $68-132$ & 65 & GAT & - & - & 2 \\
\hline $\operatorname{trn} Q$ & $\mathrm{tRNA}^{\mathrm{Gln}}$ & $\mathrm{R}$ & $135-203$ & 69 & TTG & - & - & $3 \overline{7}$ \\
\hline nad2 & NADH2 & $\mathrm{F}$ & $241-1273$ & 1033 & & ATT & TAA & -2 \\
\hline $\operatorname{trnW}$ & $\mathrm{tRNA}^{\mathrm{Trp}}$ & $\mathrm{F}$ & $1272-1340$ & 69 & TCA & - & - & -8 \\
\hline $\operatorname{trnC}$ & tRNA Cys & $\mathrm{R}$ & 1333-1398 & 66 & GCA & - & - & 14 \\
\hline $\operatorname{trn} Y$ & $\mathrm{tRNA}^{\mathrm{Tyr}}$ & $\mathrm{R}$ & $1413-1477$ & 65 & GTA & - & - & 6 \\
\hline $\operatorname{cox} 1$ & coX1 & $\mathrm{F}$ & $1484-3017$ & 1534 & & CGA & $\mathrm{T}$ & 0 \\
\hline $\operatorname{trnL2}$ & tRNA ${ }^{\text {Leu(UUR) }}$ & $\mathrm{F}$ & $3018-3084$ & 67 & TAA & - & - & 0 \\
\hline $\operatorname{cox} 2$ & COX2 & $\mathrm{F}$ & $3085-3766$ & 682 & & ATG & TA & 0 \\
\hline trnK & tRNA ${ }^{\text {Lys }}$ & $\mathrm{F}$ & 3767-3837 & 71 & CTT & - & - & -1 \\
\hline $\operatorname{trn} D$ & $\mathrm{tRNA}^{\mathrm{Asp}}$ & $\mathrm{F}$ & $3837-3902$ & 66 & GTC & - & - & 0 \\
\hline atp8 & ATP8 & $\mathrm{F}$ & $3903-4064$ & 162 & & ATT & TAA & -7 \\
\hline atp6 & ATP6 & $\mathrm{F}$ & $4058-4736$ & 679 & & ATG & TAA & 5 \\
\hline $\cos 3$ & cox3 & $\mathrm{F}$ & $4742-5538$ & 797 & & ATG & TAA & 2 \\
\hline $\operatorname{trnG}$ & tRNA ${ }^{\text {Gly }}$ & $\mathrm{F}$ & $5541-5605$ & 65 & TCC & - & - & 0 \\
\hline nad3 & NADH3 & $\mathrm{F}$ & 5606-5969 & 364 & & ATT & TAA & 2 \\
\hline $\operatorname{trn} A$ & tRNA Ala & $\mathrm{F}$ & 5972-6038 & 67 & TGC & - & - & 0 \\
\hline $\operatorname{trnR}$ & tRNA $^{\text {Arg }}$ & $\mathrm{F}$ & 6039-6100 & 62 & TCG & - & - & 0 \\
\hline $\operatorname{trn} N$ & tRNA ${ }^{\text {Asn }}$ & $\mathrm{F}$ & 6101-6166 & 66 & GTT & - & - & 9 \\
\hline $\operatorname{trnS} 1$ & tRNA ${ }^{\text {Ser(AGN) }}$ & $\mathrm{F}$ & $6176-6241$ & 66 & GCT & - & - & 3 \\
\hline $\operatorname{trnE}$ & tRNA Glu & $\mathrm{F}$ & $6245-6313$ & 69 & TTC & - & - & 9 \\
\hline $\operatorname{trnF}$ & tRNA $^{\text {Phe }}$ & $\mathrm{R}$ & $6323-6387$ & 64 & GAA & - & - & -6 \\
\hline nad5 & NADH5 & $\mathrm{R}$ & $6382-8127$ & 1746 & & ATA & TAA & 0 \\
\hline $\operatorname{trnH}$ & tRNA $^{\text {His }}$ & $\mathrm{R}$ & 8128-8194 & 66 & GTG & - & - & 0 \\
\hline nad4 & NADH4 & $\mathrm{R}$ & 8195-9530 & 1336 & & ATG & $\mathrm{T}$ & 3 \\
\hline nad5 & NADH4L & $\mathrm{R}$ & 9534-9821 & 288 & & ATG & TAA & 5 \\
\hline $\operatorname{trnT}$ & tRNA $^{\text {Thr }}$ & $\mathrm{F}$ & $9827-9891$ & 65 & TGT & - & - & 0 \\
\hline $\operatorname{trnP}$ & tRNA Pro & $\mathrm{R}$ & $9892-9957$ & 65 & TGG & - & - & 18 \\
\hline nad6 & NADH6 & $\mathrm{F}$ & 9976-10504 & 529 & & ATA & $\mathrm{T}$ & 6 \\
\hline cytb & CYTB & $\mathrm{F}$ & $10511-11672$ & 1158 & & ATG & TAA & 25 \\
\hline trnS2 & tRNA $^{\operatorname{Ser}(\mathrm{UCN})}$ & $\mathrm{F}$ & 11698-11762 & 65 & TGA & - & - & 17 \\
\hline nad1 & NADH1 & $\mathrm{R}$ & $11780-12716$ & 937 & & ATG & TAA & 1 \\
\hline $\operatorname{trnL}$ & tRNA $^{\text {Leu(CUN) }}$ & $\mathrm{R}$ & $12718-12785$ & 67 & TAG & - & - & 0 \\
\hline$r r n L$ & $16 S$ rRNA & $\mathrm{R}$ & 12786-14206 & 1421 & - & - & - & 0 \\
\hline $\operatorname{trn} V$ & tRNA ${ }^{\text {Val }}$ & $\mathrm{R}$ & $14207-14271$ & 65 & TAC & - & - & 14 \\
\hline$r r n S$ & $12 \mathrm{~S}$ rRNA & $\mathrm{R}$ & $14285-15101$ & 816 & - & - & - & 2 \\
\hline$A+T$-rich Region & & & 15104-15447 & 343 & & & & \\
\hline
\end{tabular}

of successful primers is given in Table 2 (Sangon Biotech Co., Shanghai, China). All amplifications were performed on an Eppendorf Mastercycler and Mastercycler gradient in $50 \mu \mathrm{L}$ reaction volumes, including $35 \mu \mathrm{L}$ sterilized distilled water, $5 \mu \mathrm{L} 10 \times \mathrm{Taq}$ buffer $\left(\mathrm{Mg}^{2+}\right.$ plus $), 4 \mu \mathrm{L}$ dNTP $(25 \mathrm{mM}), 1.5 \mu \mathrm{L}$ extracted DNA as a template, forward and reverse primers $2 \mu \mathrm{L}$ each $(10 \mu \mathrm{M})$ and $0.5 \mu \mathrm{L}$ (1 unit) Taq (Takara Co., Dalian, China). The PCR amplification conditions were as follows: an initial denaturation cycle at $94^{\circ} \mathrm{C}$ for $4 \mathrm{~min}$ followed by 38 cycles, one cycle at $94^{\circ} \mathrm{C}$ for $30 \mathrm{~s}$, one cycle at $48-59^{\circ} \mathrm{C}$ for $1-3 \mathrm{~min}$ (depending on putative length of the fragments), and a final extension step of one cycle at $72^{\circ} \mathrm{C}$ for $10 \mathrm{~min}$. The PCR products were detected using electrophoresis in agarose gel $(1 \%, \mathrm{w} / \mathrm{v})$, purified using a DNA gel extraction kit (Transgen Co., Beijing, China) and sequenced with the PCR primers.

\section{Sequence assembly and gene annotation}

Sequence annotation was performed using the blast tools available on NCBI (http://blast.ncbi.nlm.nih.gov/Blast) and the SeqMan II program in the Lasergene software package (DNAStar Inc., Madison, USA). The protein-coding sequences were translated into putative proteins on the basis of the Invertebrate Mitochondrial Genetic Code. The skewness was measured using the method of Junqueira et al. (2004) and base composition of nucleotide sequences was described as: AT skew $=[\mathrm{A}-\mathrm{T}] /[\mathrm{A}+\mathrm{T}], \mathrm{GC}$ skew $=[\mathrm{G}-\mathrm{C}] /[\mathrm{G}+\mathrm{C}]$. The Relative Synonymous Codon Usage (RSCU) values were calculated using MEGA 5.0 (Tamura et al., 2011).

Transfer RNA genes were determined using tRNAscan-SE software (http://lowelab.ucsc.edu/tRNAscan-SE/) (Lowe \& Eddy, 1997), or predicted by sequence features of being capable of folding into the typical cloverleaf secondary structure with legitimate anticodon. The tandem repeats in the A+T-rich region were found using the Tandem Repeats Finder program (http:// tandem.bu.edu/trf/trf.html) (Benson, 1999).

\section{Phylogenetic analysis}

To reconstruct the phylogenetic relationships of Lepidoptera, 38 complete or partially complete mitogenomes were downloaded from the GenBank database (Table 1). The mitogenomes of Drosophila melanogaster (U37541.1) (Lewis et al., 1995) and Locusta migratoria (NC_001712) (Flook et al., 1995) were used as an outgroup. The amino acid sequences of each of the 13 mitochondrial PCGs were aligned with Clustal X using default settings and concatenated (Thompson et al., 1997). Later a concatenated set of amino acid sequences from the 13 PCGs was used for phylogenetic analyses, which were performed using the Maximum Likelihood (ML) method with the MEGA version 5.1 program (Tamura et al., 2011). The method was used to infer phylogenetic trees based on 1000 bootstrap replicates.

\section{RESULTS}

\section{Genome structure, organization and composition}

The complete mitogenome of $S$. robusta is a closed circular molecule, 15,447 bp long (Fig. 1). The complete mitogenome is deposited in NCBI GenBank database under accession number KX753670. It contains the entire set of 37 genes (22 tRNA genes, 13 PCGs [nad1-6, nad4L, cox1-3, cob, atp6 and atp8], two rRNAs [ $r r n S$ and $r r n L]$. In addition, there is one major non-coding $\mathrm{A}+\mathrm{T}$-rich region 

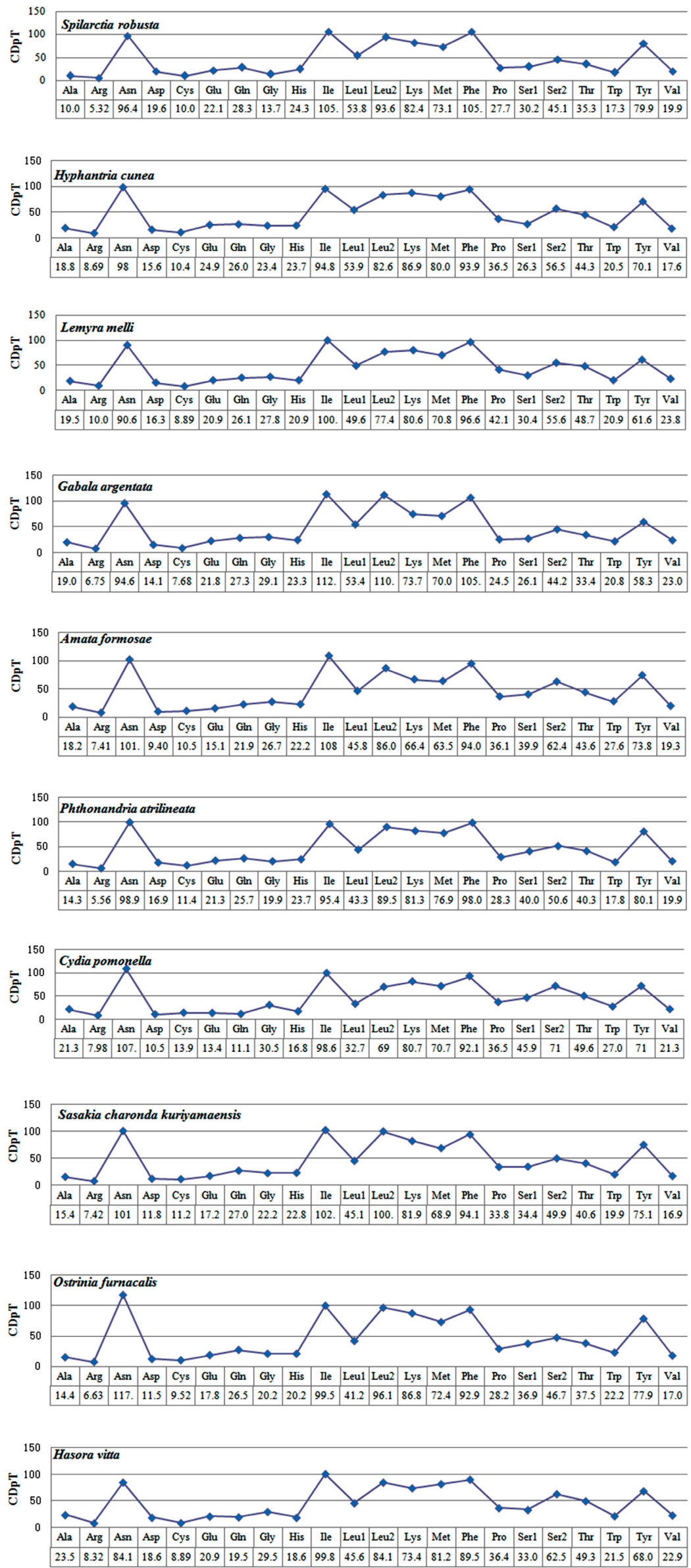

Fig. 3. Distribution of the codons in different species of Lepidoptera. CDspT - codons per thousand codons. 
Table 4. Composition and skewness of different lepidopteran mitogenomes.

\begin{tabular}{|c|c|c|c|c|c|c|c|c|}
\hline Species & Size (bp) & $A \%$ & G\% & $\mathrm{T} \%$ & $\mathrm{C} \%$ & $\mathrm{~A}+\mathrm{T} \%$ & AT skewness & GC skewness \\
\hline \multicolumn{9}{|l|}{ Whole genome } \\
\hline S. robusta & 15,447 & 40.28 & 7.57 & 40.81 & 11.34 & 81.09 & -0.007 & -0.199 \\
\hline L. melli & 15,418 & 39.38 & 8.72 & 39.29 & 13.06 & 78.67 & 0.001 & -0.199 \\
\hline H. cunea & 15,481 & 40.58 & 7.55 & 39.81 & 12.06 & 80.39 & 0.010 & -0.230 \\
\hline A. formosae & 15,463 & 38.67 & 7.53 & 40.83 & 12.98 & 79.49 & -0.027 & -0.266 \\
\hline G. argentata & 15,337 & 39.64 & 7.56 & 42.05 & 10.75 & 81.69 & 0.030 & -0.174 \\
\hline S. morio & 15,299 & 40.64 & 7.58 & 40.53 & 11.23 & 81.17 & 0.001 & -0.194 \\
\hline C. pomonella & 15,253 & 39.92 & 7.88 & 40.21 & 11.99 & 80.13 & -0.004 & -0.207 \\
\hline$P$. atrilineata & 15,499 & 40.78 & 7.67 & 40.24 & 11.31 & 81.02 & 0.007 & -0.192 \\
\hline S. c. kuriyamaensis & 15,222 & 39.68 & 7.86 & 40.21 & 12.25 & 79.89 & -0.007 & -0.218 \\
\hline O. furnacalis & 14,536 & 41.46 & 7.91 & 38.92 & 11.71 & 80.37 & 0.032 & -0.194 \\
\hline H. vitta & 15,282 & 39.58 & 7.81 & 40.34 & 12.27 & 79.92 & -0.010 & -0.222 \\
\hline B. mandarina & 15,682 & 43.11 & 7.40 & 38.48 & 11.01 & 81.59 & 0.057 & -0.196 \\
\hline A. pernyi & 15,566 & 39.22 & 7.77 & 40.94 & 12.07 & 80.16 & -0.021 & -0.216 \\
\hline M. sexta & 15,516 & 40.67 & 7.46 & 41.11 & 10.76 & 81.79 & -0.005 & -0.181 \\
\hline C. suppressalis & 15,395 & 40.64 & 7.39 & 40.03 & 11.94 & 80.67 & 0.007 & -0.235 \\
\hline \multicolumn{9}{|l|}{ PCG } \\
\hline S. robusta & 11,120 & 39.31 & 7.65 & 41.47 & 11.57 & 80.77 & -0.027 & -0.204 \\
\hline L. melli & 11,120 & 38.47 & 9.17 & 38.17 & 14.19 & 76.64 & 0.004 & -0.215 \\
\hline H. cunea & 11,198 & 39.98 & 8.35 & 38.61 & 13.06 & 78.59 & 0.017 & -0.220 \\
\hline A. formosae & 11,217 & 38.18 & 8.28 & 39.62 & 13.92 & 77.80 & -0.019 & -0.254 \\
\hline G. argentata & 10,303 & 38.10 & 8.61 & 41.88 & 11.41 & 79.98 & -0.047 & -0.140 \\
\hline S. morio & 11,179 & 40.28 & 8.27 & 39.56 & 11.89 & 79.84 & 0.009 & -0.180 \\
\hline C. pomonella & 11,199 & 39.55 & 8.69 & 39.00 & 12.76 & 78.55 & 0.007 & -0.190 \\
\hline$P$. atrilineata & 11,203 & 40.23 & 8.59 & 38.87 & 12.31 & 79.10 & 0.017 & -0.178 \\
\hline S. c. kuriyamaensis & 10,795 & 39.39 & 8.62 & 38.92 & 13.08 & 78.30 & 0.006 & 0.997 \\
\hline O. furnacalis & 11,194 & 41.16 & 8.43 & 38.26 & 12.14 & 79.42 & 0.037 & -0.180 \\
\hline H. vitta & 11,202 & 38.76 & 8.61 & 39.43 & 13.20 & 78.19 & -0.009 & -0.210 \\
\hline B. mandarina & 11,196 & 42.83 & 8.26 & 37.04 & 11.87 & 79.87 & 0.072 & -0.179 \\
\hline A. pernyi & 11,204 & 39.22 & 7.77 & 40.94 & 12.07 & 80.16 & -0.021 & -0.216 \\
\hline M. sexta & 11,185 & 40.41 & 8.23 & 39.88 & 11.48 & 80.30 & 0.007 & -0.165 \\
\hline C. suppressalis & 11,230 & 40.42 & 8.16 & 38.48 & 12.95 & 78.90 & 0.025 & -0.227 \\
\hline \multicolumn{8}{|l|}{ tRNA } & -0.163 \\
\hline S. robusta & 1,473 & 41.00 & 8.21 & 40.19 & 10.59 & 81.19 & 0.010 & -0.127 \\
\hline L. melli & 1,486 & 40.58 & 8.55 & 40.24 & 10.63 & 80.82 & 0.004 & -0.109 \\
\hline H. cunea & 1,463 & 41.83 & 7.86 & 39.99 & 10.32 & 81.82 & 0.022 & -0.135 \\
\hline A. formosae & 1,457 & 40.43 & 7.96 & 40.36 & 11.26 & 80.78 & 0.001 & -0.172 \\
\hline G. argentata & 1,468 & 41.35 & 8.24 & 40.19 & 10.22 & 81.54 & 0.014 & -0.107 \\
\hline S. morio & 1,462 & 40.63 & 8.21 & 40.97 & 10.19 & 81.60 & -0.004 & -0.107 \\
\hline C. pomonella & 1,464 & 41.19 & 7.92 & 40.23 & 10.66 & 81.42 & 0.012 & -0.147 \\
\hline$P$. atrilineata & 1,476 & 41.4 & 8.2 & 40.04 & 10.37 & 81.44 & 0.017 & -0.117 \\
\hline S. c. kuriyamaensis & 1,459 & 40.85 & 8.09 & 40.37 & 10.69 & 81.22 & 0.006 & -0.138 \\
\hline O. furnacalis & 1,433 & 42.22 & 8.03 & 39.01 & 10.75 & 81.23 & 0.040 & -0.145 \\
\hline H. vitta & 1,456 & 41.41 & 8.04 & 39.84 & 10.71 & 81.25 & 0.019 & -0.142 \\
\hline B. mandarina & 1,472 & 41.78 & 7.81 & 39.95 & 10.46 & 81.73 & 0.022 & -0.145 \\
\hline A. pernyi & 1,459 & 39.22 & 7.77 & 40.94 & 12.07 & 80.16 & -0.021 & -0.217 \\
\hline M. sexta & 1,554 & 40.99 & 7.92 & 41.06 & 10.04 & 82.05 & -0.001 & -0.118 \\
\hline C. suppressalis & 1,482 & 40.89 & 7.89 & 40.89 & 10.32 & 81.78 & 0.000 & -0.133 \\
\hline \multicolumn{9}{|l|}{ rRNA } \\
\hline S. robusta & 2,238 & 42.14 & 4.65 & 43.3 & 9.92 & 85.43 & -0.014 & -0.362 \\
\hline L. melli & 2,233 & 42.23 & 4.93 & 41.96 & 10.88 & 84.19 & 0.003 & -0.376 \\
\hline H. cunea & 2,234 & 42.08 & 4.92 & 42.75 & 10.25 & 84.83 & -0.008 & -0.351 \\
\hline A. formosae & 2,163 & 38.93 & 4.72 & 44.85 & 11.51 & 83.77 & -0.071 & -0.418 \\
\hline G. argentata & 2,165 & 40.6 & 4.76 & 45.13 & 9.52 & 85.73 & -0.053 & -0.333 \\
\hline S. morio & 2,152 & 41.73 & 4.83 & 43.08 & 10.36 & 84.8 & -0.016 & -0.364 \\
\hline C. pomonella & 2,147 & 40.48 & 5.03 & 43.92 & 10.57 & 84.4 & -0.041 & -0.355 \\
\hline$P$. atrilineata & 2,203 & 42.85 & 4.58 & 43.08 & 9.49 & 85.93 & -0.003 & -0.349 \\
\hline S. c. kuriyamaensis & 2,086 & 39.98 & 5.18 & 44.53 & 10.31 & 84.52 & -0.054 & -0.331 \\
\hline O. furnacalis & 1,774 & 42.39 & 5.07 & 42.05 & 10.48 & 84.44 & 0.004 & -0.348 \\
\hline H. vitta & 2,194 & 41.43 & 4.88 & 43.25 & 10.44 & 84.69 & -0.021 & -0.363 \\
\hline B. mandarina & 2,134 & 43.86 & 4.78 & 41.05 & 10.31 & 84.91 & 0.033 & -0.366 \\
\hline A. pernyi & 2,144 & 39.22 & 7.77 & 40.94 & 12.07 & 80.16 & -0.021 & -0.217 \\
\hline M. sexta & 2,168 & 41.37 & 4.84 & 44.05 & 9.73 & 85.42 & -0.031 & -0.336 \\
\hline C. suppressalis & 2,171 & 41.27 & 4.97 & 43.67 & 10.09 & 84.94 & -0.028 & -0.340 \\
\hline A. ipsilon & 2,162 & 41.58 & 5 & 43.57 & 9.85 & 85.15 & -0.023 & -0.327 \\
\hline S. robusta & 344 & 45.35 & 0.58 & 50 & 4.07 & 95.35 & -0.049 & -0.751 \\
\hline L. melli & 338 & 43.2 & 1.48 & 51.18 & 4.14 & 94.38 & -0.085 & -0.473 \\
\hline H. cunea & 357 & 45.66 & 1.12 & 49.3 & 3.92 & 94.96 & -0.038 & -0.556 \\
\hline A. formosae & 482 & 42.95 & 2.9 & 49.79 & 4.36 & 92.74 & -0.074 & -0.201 \\
\hline G. argentata & 340 & 43.24 & 1.47 & 52.06 & 3.24 & 95.29 & -0.093 & -0.376 \\
\hline S. morio & 316 & 44.3 & 2.53 & 48.42 & 4.75 & 92.72 & -0.044 & -0.305 \\
\hline C. pomonella & 351 & 43.3 & 1.14 & 52.42 & 3.13 & 95.73 & -0.095 & -0.466 \\
\hline$P$. atrilineata & 457 & 40.7 & 0.66 & 57.55 & 1.09 & 98.25 & -0.172 & -0.246 \\
\hline S. c. kuriyamaensis & 380 & 44.74 & 3.68 & 47.11 & 4.47 & 91.84 & -0.026 & -0.097 \\
\hline H. vitta & 255 & 45.88 & 2.75 & 48.24 & 3.14 & 94.12 & -0.025 & -0.066 \\
\hline B. mandarina & 484 & 46.49 & 2.69 & 47.93 & 2.89 & 94.42 & -0.015 & -0.036 \\
\hline A. pernyi & 552 & 39.22 & 7.77 & 40.94 & 12.07 & 80.16 & -0.021 & -0.216 \\
\hline M. sexta & 324 & 45.06 & 1.54 & 50.31 & 3.09 & 95.37 & -0.005 & -0.335 \\
\hline C. suppressalis & 348 & 42.24 & 0.29 & 53.16 & 4.31 & 95.4 & -0.114 & -0.874 \\
\hline A. ipsilon & 332 & 46.08 & 1.51 & 48.8 & 3.61 & 94.88 & -0.029 & -0.41 \\
\hline
\end{tabular}



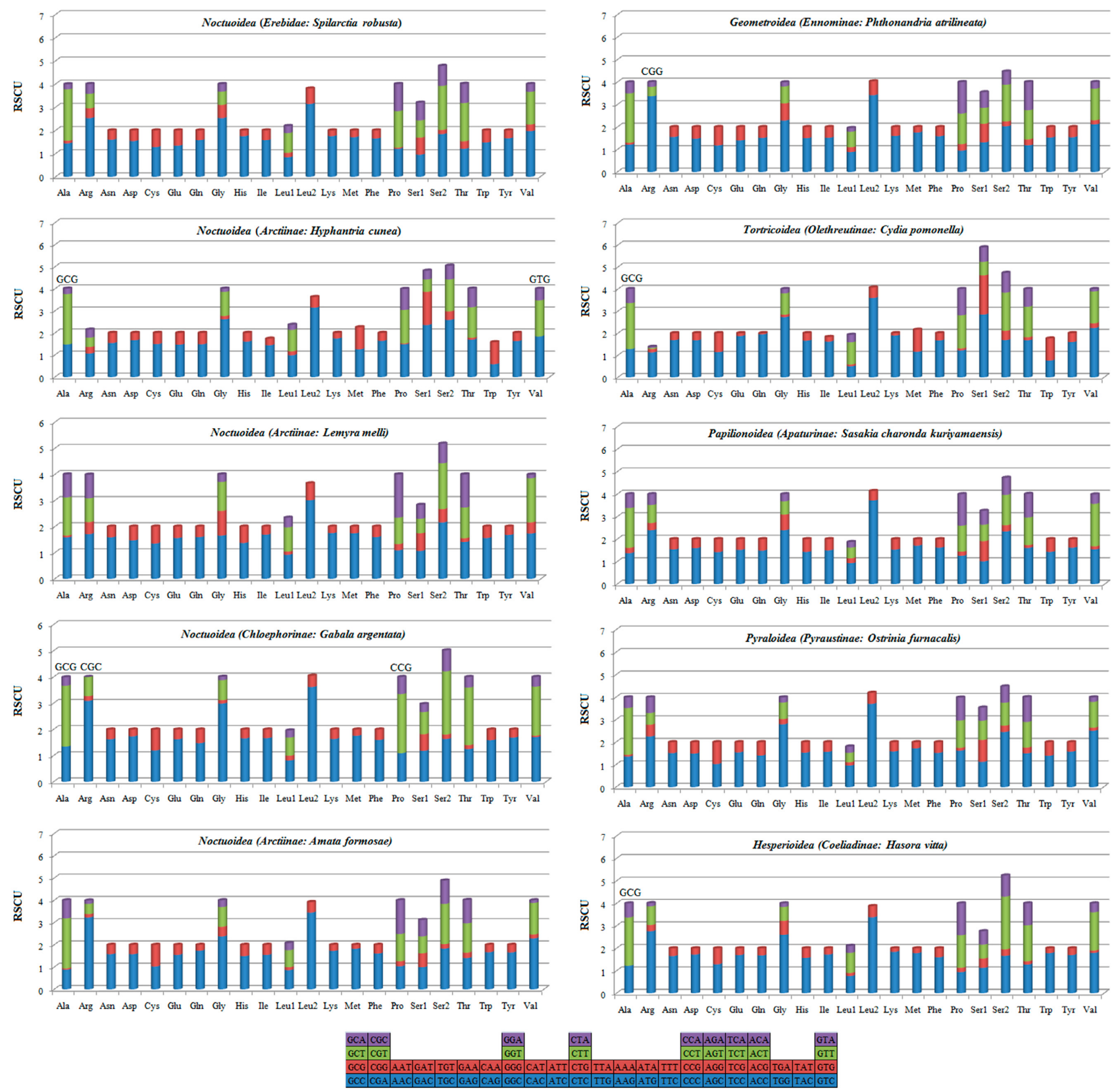

Fig. 4. The Relative Synonymous Codon Usage (RSCU) of the mitochondrial genome in six super families of Lepidoptera. Codon families are plotted on the $\mathrm{x}$-axis. Codons indicated above the bar are not present in the mitogenomes.

(Table 3). The gene arrangement and orientation is trnMtrnI-trnQ. The nucleotide composition of the major strand is $40.28 \% \mathrm{~A}, 40.81 \% \mathrm{~T}$, and $7.57 \% \mathrm{G}$ and: $11.34 \% \mathrm{C}$, with a total of $81.09 \% \mathrm{~A}+\mathrm{T}$ content (Table 4 ). The AT skewness and GC skewness are -0.007 and -0.199 , respectively.

\section{Protein-coding genes and codon usage}

Twelve of the 13 PCGs of $S$. robusta use ATN (ATT, ATG and ATA) as an initiation codon. Of which, the ATG is the most frequent initiation codon as the cox2, cox3, atp 6 , nad4, nad4L, cytb and nadl begin with it. Whereas coxl has a CGA start codon. Four of the 13 PCGs ( $\operatorname{cox} 1$, cox 2 , nad6 and nad4) terminate with incomplete stop codons, either TA or T nucleotide, and the remainder of the PCGs terminate with the canonical stop codon TAA. The coxl, nad4 and nad6 have a single $\mathrm{T}$ as a stop codon, while the cox2 has TA. We analyzed the codon usage of ten lepidopteran species, of which five belonged to Noctuoidea and one each to Geometroidea, Tortricoidea, Papilionoidea, Pyraloidea and Hesperioidea (Fig. 2). The analysis reveals that Asn, Ile, Leu2, Lys, Phe, Tyr and Met are the most frequently utilized amino acids, of which, the hydrophobic amino acid Leu2 family is the most and the Arg codon family the least frequent. The codon distribution of five Noctuoidea species is consistent, and the content of each amino acid is similar in the different species (Fig. 3).

The Relative Synonymous Codon Usage (RSCU) in the six lepidopteran superfamilies with known mitogenomes reveals that $S$. robusta PCGs are relatively similar to those of $L$. melli, A. formosae, $S$. charonda kuriyamaensis and $O$. furnacalis, and different from the species, which lack GCG 

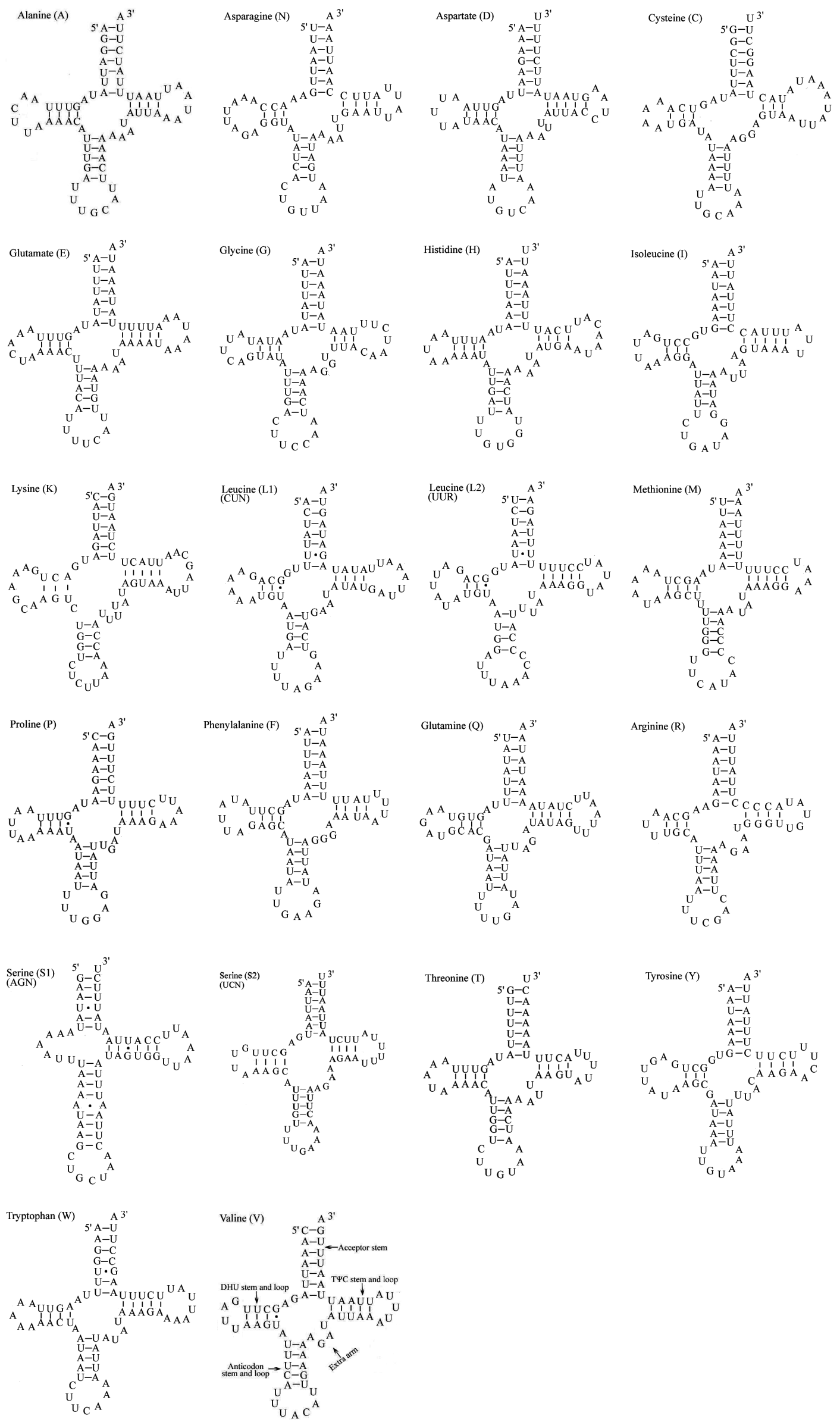

Fig. 5. Putative secondary structures of the 22 tRNAs of the mitogenome of $S$. robusta. 


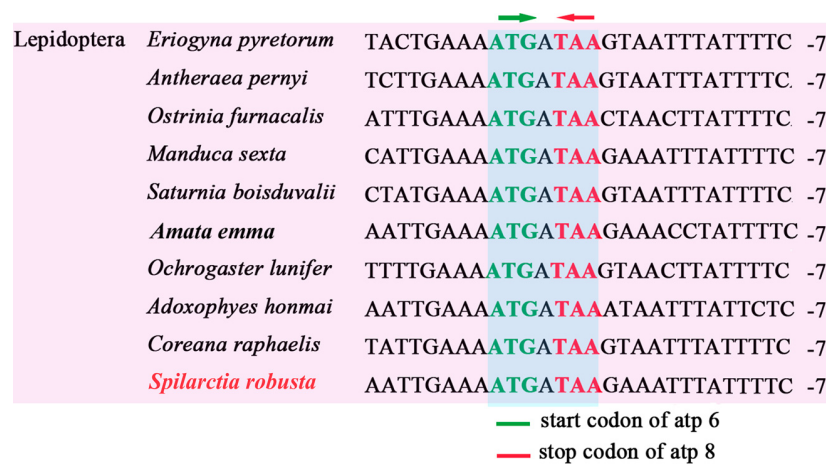

Fig. 6. Alignment of the overlapping region between atp8 and atp6 in Lepidoptera and other insects. The numbers on the right refer to the number of intergenic nucleotides.

\& GTG (H. cunea), GCG \& CGC \& CCG ( $G$. argentata), CGG (P. atrilineata), GCG (C. pomonella) and GCG $(H$. vitta) Codons (Fig. 4).

\section{Ribosomal and tRNA genes}

As in other Lepidoptera, S. robusta has two rRNA genes. The $r r n L$ gene $(1421 \mathrm{bp})$ is at the junction between tRNA $^{\text {Leu }}(\mathrm{CUN})-\mathrm{tRNA} \mathrm{V}^{\mathrm{Val}}$ and the $r r n S$ gene $(816 \mathrm{bp})$, which is located between $\mathrm{tRNA}^{\mathrm{Val}}$ and the $\mathrm{A}+\mathrm{T}$-rich region (Table 3 ), and the $\mathrm{A}+\mathrm{T}$ content is $83.81 \%$. The value of the $\mathrm{A}+\mathrm{T}$ content is well within the range of $80.16 \%$ (B. mandarina) to $85.93 \%$ ( $P$. atrilineata) recorded for Lepidotera. Both the AT skewness $(-0.014)$ and GC skewness $(-0.362)$ are negative.

Fourteen of the 22 tRNA genes on the H-strand and eight on the L-strand were identified. The length of tRNA genes ranges from $62 \mathrm{bp}$ to $71 \mathrm{bp}$, which is similar to that of most Lepidoptera sequenced. It is highly $\mathrm{A}+\mathrm{T}(81.19 \%)$ biased, and exhibits positive AT-skewness (0.010) and negative GC skewness $(-0.127)$ (Table 4). All the tRNAs fold into the expected secondary cloverleaf structure, with the exception of tRNA $^{\mathrm{Ser}(\mathrm{AGN})}$ (Fig. 5). It forms an unusual secondary structure lacking a stable stem-loop structure in the DHU arm. There are a total of 11 mismatches in S. robusta
tRNA genes. The G-U wobble pairs are scattered throughout the 6 tRNA genes, (two in the acceptor stem, four in DHU and one in $\mathrm{T} \psi \mathrm{C}$ ) and there is one A-A mismatch in the anticodon stem of trnS1 and three U-U mismatches in the acceptor stem of $\operatorname{trnA}$, trnL2 and trnS1 (Fig. 5).

\section{Overlapping and intergenic spacer regions}

There are five overlapping regions, with a total of $24 \mathrm{bp}$ in the mitogenome of $S$. robusta. On the basis of their location, they are categorized into three types: tRNA and tRNA (trn $W$ and $\operatorname{trn} C, \operatorname{trn} K$ and $\operatorname{trn} D$ ), tRNA and protein ( $n a d 2$ and $t r n W, t r n F$ and $n a d 5$ ) and protein and protein (atp6 and atp8). The length of these sequences varies from $1 \mathrm{bp}$ to 8 $\mathrm{bp}$. The largest overlapping region ( $8 \mathrm{bp})$, located between $\operatorname{trn} W$ and $\operatorname{trn} C$, the rest of $6 \mathrm{bp}, 2 \mathrm{bp}$, and $1 \mathrm{bp}$ overlaps located between $\operatorname{trn} F$ and nad5, nad2 and $\operatorname{trn} W$, and $\operatorname{trn} K$ and $\operatorname{trn} W$, respectively (Table 3 ). In addition, there is a 7 bp overlap located at the junction of atp8-atp6. Further we recorded intergenic nucleotides between atp 8 and atp 6 in ten species of Lepidoptera (Fig. 6).

The intergenic spacers in the mitogenome of $S$. robusta are spread over 18 regions and ranged in size from $1 \mathrm{bp}$ to $37 \mathrm{bp}$, with a total of $168 \mathrm{bp}$ in length. Of which there are six major intergenic spacers of at least $10 \mathrm{bp}$ in length (Table 3). The largest intergenic spacer (37 bp) is present between $\operatorname{trn} Q$ and $n a d 2$ and has an extremely high $\mathrm{A}+\mathrm{T}$ content. Further we identified a 17 bp intergenic spacer between $\operatorname{trnS2}(\mathrm{UCN})$ and nad1, which contains the "ATACTAA" motif (Fig. 7A).

\section{The A+T-rich region}

With a length of $344 \mathrm{bp}$, the A+T-rich region in the mitogenome of $S$. robusta is located at the junction $r r n S$ $\operatorname{trnM}$ (Table 4). This region has the highest $\mathrm{A}+\mathrm{T}(95.35 \%)$ content, and most negative AT skewness (-0.049) and GC skewness $(-0.751)$ (Table 4$)$. We recorded four short repeating sequences located on both sides of the A+T-rich region, the motif "ATAGA" and a 19 bp poly-T stretch downstream from the $r r n S$ gene, while the microsatellite-
A

Spilarctia robusta (Lepidoptera: Erebidae)
Amata formosae (Lepidoptera: Erebidae)
Spodoptera litura (Lepidoptera: Noctuidae)
Lymantria dispar (Lepidoptera: Lymantriidae)
Ochrogaster lunifer (Lepidoptera: Notodontidae)
Bombyx mori (Lepidoptera: Bombycidae)
Antheraea pernyi (Lepidoptera: Saturniidae)
Tyspanodes hypsalis (Lepidoptera: Crambidae)
Lista haraldusalis (Lepidoptera: Pyralidae)
Grapholita dimorpha (Lepidoptera: Tortricidae)
Luehdorfia taibai (Lepidoptera: Papilionidae)

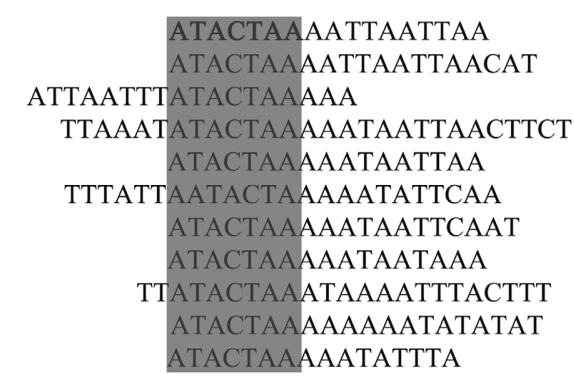

B rrns-15,104-CACATAGATTTTTTTTTTTTTTTTTTTATATTTAAATATTTAATATAATAAAAATTTTTA TATTAAATATTTAATATTAATTATTAAATTTTTAATAATTTCTCTTTTTTTTTCTTTATAATATTAA TATTAAAACCTAAATTGCTATATCAAACAATTATAATTTAATAAATTATAAAAAATTAATATTAA TAATATTAATTTTTTTAATAATTTATTATATTATATTATATATTAATAAATTAAATATTTAATATAT ATATATATATATTAACATTAATTTTTTATTTAATTAATAATCTAAACCATTTTTAATAAATATATA TATAAAATAAAAAAAAAAA-15,447-trnM

Fig. 7. (A) Alignment of the intergenic spacer region between trnS2 (UCN) and nad1 in several species of Lepidoptera. The shaded "ATACTAA" motif is conserved in Lepidoptera. (B) Features present in the A+T-rich region in S. robusta. The sequence is shown in the reverse strand. The ATATG motif is shaded. The poly-T stretch is underlined, while the poly-A stretch is double underlined. The single microsatellite T/A repeats sequence are indicated by dotted underlining. 


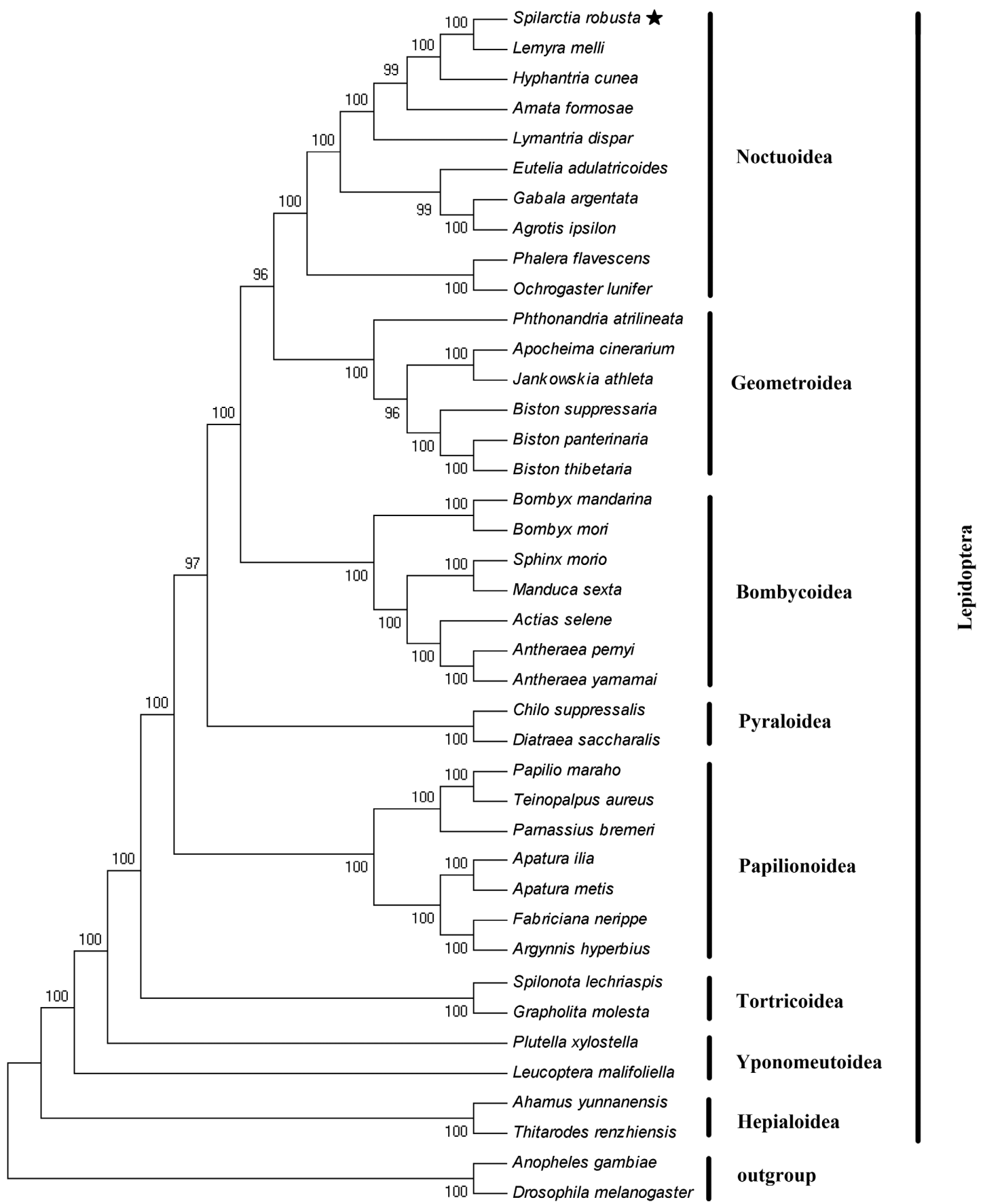

Fig. 8. Tree showing the phylogenetic relationships of Lepidoptera, constructed using the Maximum Likelihood method. Bootstrap values (1000 repetitions) of the branches are indicated. Anopheles gambiae (L20934.1) and Drosophila melanogaster (U37541.1) were used as outgroups.

like element $(\mathrm{AT})_{9}$ and a poly-A element are located upstream of the trnM gene (Fig. 7B).

\section{Phylogenetic relationships}

We reconstructed the phylogenetic relationships using the ML method based on the concatenated nucleotide sequences of the 13 PCGs of the related lepidopteran superfamilies. The phylogenetic analysis reveals that the superfamilies Noctuoidea, Geometroidea, Bombycoidea, Pyraloidea, Papilionoidea, Tortricoidea, Yponomeutoidea and Hepialoidea are monophyletic (Table 1), and Noctuoidea is most closely related to the superfamilies Ge- ometroidea and Bombycoidea. Different species of the same family form a single cluster and $S$. robusta is closely related to L. melli in the Erebidae (Fig. 8).

\section{DISCUSSION}

In the present study, the size of the newly sequenced $S$. robusta $(15,447 \mathrm{bp})$ mitogenome falls within the range of those recorded for other species of Lepidoptera sequenced; Artogeia $(15,140 \mathrm{bp})$ has the shortest and B. mandarina $(15,928)$ the longest. The variation in size is primarily due to differences in the number of repeats in the control regions (Pan et al., 2008; Hong et al., 2009). The gene number and 
nucleotide composition is similar to that of Metazoa, however their arrangement and orientation (trnM-trnI-trnQ) is different from the ancestral gene order trnI-trnQ-trnM (Boore, 1999). The AT skewness $(-0.007)$ of the mitogenome studied indicates the presence of less As than Ts. This remarkable feature is also reported for several arthropod species including $A$. formosae $(-0.027)$, C . pomonella (-0.004), H. vitta $(-0.010)$ and $A$. pernyi $(-0.021)$. Interestingly, the GC skewness $(-0.362)$ of the rRNA is much lower than in previously sequenced animals and further reveals that the mitgenome is more biased toward Cs than Gs (Jiang et al., 2009; Liu et al., 2012).

Twelve of the 13 protein-coding genes have the standard ATN (ATT, ATG and ATA) start codon, while cox 1 has CGA. Most of $S$. robusta PCGs (cox2, cox3, atp6, nad4, nad4L, cytb and nadl) have ATG as the initiation codon (Dai et al., 2016, Liu et al., 2016). Four PCGs (cox1, cox2, nad6 and nad4) have incomplete stop codons, either TA or $\mathrm{T}$, while the remaining end with TAA. Partial stop codons are reported in many lepidopteran mitogenomes. In Lepidoptera there seems to be a high degree of conservation of incomplete stop codons (Liao et al., 2010; Liu et al., 2013).

The comparative analysis of the different codons in ten species of Lepidoptera (Fig. 2) reveals that Asn, Ile, Leu2, Lys, Phe, Tyr and Met are the most frequent amino acids, of which the Leu2 family (hydrophobic amino acid) the most frequent. The composition of amino acid might be related to the function of the chondriosome in encoding several transmembrane proteins (Lu et al., 2013). Furthermore, the relative codon usage (RSCU) recorded for $S$. robusta is similar to that for L. melli, A. formosae, S. charonda kuriyamaensis and $O$. furnacalis, but different from that recorded for the codons of species that lack GCG\&GTG (H. cunea), GCG\&CGC\&CCG (G. argentata), CGG ( $P$. atrilineata), GCG (C. pomonella) and GCG (H. vitta). It is likely there are fewer codons with a high $\mathrm{GC}$, as this feature seems to be conserved in insects ( $\mathrm{Lu}$ et al., 2013; Dai et al., 2015).

Five overlaps, with a total length of $24 \mathrm{bp}$ were recorded in the mitogenome of $S$. robusta. The largest 8 bp overlap is between $\operatorname{trn} W$ and $\operatorname{trn} C$ (Table 3 ) as documented for other species of Lepidoptera, for instance $B$. mandarina $(\mathrm{Li}$ et al., 2010) and B. mori Dazao (Liu et al., 2013). An interesting aspect of the present study is the finding that there is an overlapping sequence of $7 \mathrm{bp}$ (ATGATAA) at the junction of the atp8-atp6 genes. This overlap seems to be conserved in the Lepidoptera currently sequenced (Liu et al., 2008; Zhu et al., 2013). The overall organization of the mitogenome of $S$. robusta is compact, with only $168 \mathrm{bp}$ intergenic spacers dispersed in 18 regions and ranging in size from 1 to $37 \mathrm{bp}$ (Table 3 ). The longest intergenic spacer (37 bp) is located at the junction $\operatorname{trn} Q-n a d 2$, with an extremely high $\mathrm{A}+\mathrm{T}$ content, which is frequently recorded in the mitogenomes of Lepidoptera (He et al., 2015). The intergenic spacers in the mitogenome studied is longer than that in $A$. selene (137 bp over 13 regions), but shorter than that in $O$. lunifer (371 bp over 20 regions) (Salvato et al., 2008; Liu et al., 2012). The $17 \mathrm{bp}$ spacer between trnS2 (UCN) and nadl contains the "ATACTAA" motif (Fig. 7A), which is a highly conserved region in most insect mtDNAs and is proposed as a possible mitochondrial transcription termination peptide-binding site (mtTERM protein) (Taanman, 1999).

The AT-rich region in the mitogenomes of arthropods is a non-coding stretch, usually located between the trnI-trnQ$\operatorname{trnM}$ gene cluster and the $r r n S$ gene. The occurrence of different copy numbers of tandemly repeated elements is documented as one of the remarkable features of the A+Trich region in insects. The $\mathrm{A}+\mathrm{T}-$ rich region in $S$. robusta extends over $344 \mathrm{bp}(15,104-15,447)$ and is located between $r r n S$ and $\operatorname{trn} M$. The region is highly $\mathrm{A}+\mathrm{T}(95.35 \%)$ biased compared to the mitogenome as a whole $(81.09 \%)$. The first two repeat regions, the motif "ATAGA" and the 19 bp poly-T stretch are located on the $r r n S$ gene side of the A+T-rich region, while the microsatellite-like (AT), and poly-A element are located upstream of the $\operatorname{trn} M$ gene (Fig. 7B). Comparison with other previously sequenced lepidopterans revealed that the $\mathrm{A}+\mathrm{T}$-rich region of the mitogenome studied is longer than that in L. melli (338 bp), G. argentata (340 bp), S. morio (316 bp), H. vitta (255 bp), M. sexta (324 bp) and A. ipsilon (332 bp), but shorter than that in H. cunea (357 bp), A. formosae (482 bp), C. pomonella (351 bp), P. atrilineata (457 bp), B. mandarina (484 $\mathrm{bp}$ ), A. pernyi (552 bp) and C. suppressalis (348 bp) (Table 4). The length of the poly-T stretch varies from species to species (Lu et al., 2013; Dai et al., 2015) and the ATAGA region is conserved in Lepidoptera (Cameron \& Whiting, 2008).

The phylogenetic analyses revealed that the different species from the same family clustered together. These results are consistent with the conclusion of many authors, e.g. Liu et al. (2015) and Lammermann et al. (2016). Results of further analyses strongly support a close relationship between $S$. robusta and L. melli (Erebidae).

ACKNOWLEDGMENTS. This work was supported by the earmarked fund for modern Argoindustry Technology Research System (CARS-22 SYZ10), Key Biological Subjects of Anhui Province, the National Natural Science Foundation of China (31301715), the Sericulture Biotechnology Innovation Team (2013xkdt-05), the National Natural Science Foundation of China (31472147), the Ph.D. Programs in Biochemistry and Molecular Biology (xk2013042), the National Natural Science Foundation of China (31402018), and the Graduate Student Innovation Fund of Anhui Agricultural University (2015-34).

\section{REFERENCES}

Babbucci M., Basso A., Scupola A., Patarnello T. \& Negrisolo E. 2014: Is it an ant or a butterfly? Convergent evolution in the mitochondrial gene order of Hymenoptera and Lepidoptera. Genome Biol. Evol. 6: 3326-3343.

Benson G. 1999: Tandem repeats finder: A program to analyze DNA sequences. - Nucl. Acids Res. 27: 573-580.

Boore J.L. 1999: Animal mitochondrial genomes. - Nucl. Acids Res. 27: 1767-1780.

CAmeron S.L. 2014: Insect mitochondrial genomics: Implications for evolution and phylogeny. - Annu. Rev. Entomol. 59: 95-117. 
CAmeron S.L. \& Whiting M.F. 2008: The complete mitochondrial genome of the tobacco hornworm, Manduca sexta (Insecta: Lepidoptera: Sphingidae), and an examination of mitochondrial gene variability within butterflies and moths. - Gene $\mathbf{4 0 8}$ : $112-123$.

CAO Y.Q., Ma C.A., Chen J.Y. \& YANG D.R. 2012: The complete mitochondrial genomes of two ghost moths, Thitarodes renzhiensis and Thitarodes yunnanensis: The ancestral gene arrangement in Lepidoptera. - BMC Genomics 13: 276, 13 pp.

Chai H.N., Du Y.Z. \& Zhai B.P. 2012: Characterization of the complete mitochondrial genomes of Cnaphalocrocis medinalis and Chilo suppressalis (Lepidoptera: Pyralidae). - Int. J. Biol. Sci. 8: 561-579.

Chen M., Tian L.L., Shi Q.H., Cao T.W. \& Hao J.S. 2012: Complete mitogenome of the lesser purple emperor Apatura ilia (Lepidoptera: Nymphalidae: Apaturinae) and comparison with other nymphalid butterflies. - Dongwuxиe Yanjiu 33: 191201.

Chen S.C., Wang X.Q., Wang J.J., Hu X. \& Peng P. 2016: The complete mitochondrial genome of a tea pest looper, Buzura suppressaria (Lepidoptera: Geometridae). - Mitochondrial DNA 27: 3153-3154.

Dai L., Qian C., Zhang C., Wang L., Wei G., Li J., Zhu B. \& LiU C. 2015: Characterization of the complete mitochondrial genome of Cerura menciana and comparison with other lepidopteran insects. - PloS ONE 10(8): e0132951, 17 pp.

Dai L.S., Zhu B.J., Qian C., Zhang C.F., Li J., Wang L., Wei G.Q. \& Liu C.L. 2016: The complete mitochondrial genome of the diamondback moth, Plutella xylostella (Lepidoptera: Plutellidae). - Mitochondrial DNA 27: 1512-1513.

Flook P.K., Rowell C.H. \& Gellissen G. 1995: The sequence, organization, and evolution of the Locusta migratoria mitochondrial genome. - J. Mol. Evol. 41: 928-941.

Gong Y.J., Shi B.C., Kang Z.J., Zhang F. \& Wei S.J. 2012: The complete mitochondrial genome of the oriental fruit moth Grapholita molesta (Busck) (Lepidoptera: Tortricidae). Mol. Biol. Rep. 39: 2893-2900.

Hao J., Sun Q., Zhao H., Sun X., Gai Y. \& Yang Q. 2012: The complete mitochondrial genome of Ctenoptilum vasava (Lepidoptera: Hesperiidae: Pyrginae) and its phylogenetic implication. - Comp. Funct. Genomics 2012: 328049, 13 pp.

He S.L., Zou Y., Zhang L.F., Ma W.Q., Zhang X.Y. \& Yue B.S 2015: The complete mitochondrial genome of the beet webworm, Spoladea recurvalis (Lepidoptera: Crambidae) and its phylogenetic implications. - PloS ONE 10: e0129355, 20 pp.

Hong G., Jiang S., Yu M., Yang Y., Li F., Xue F. \& Wei Z. 2009: The complete nucleotide sequence of the mitochondrial genome of the cabbage butterfly, Artogeia melete (Lepidoptera: Pieridae). - Acta Biochim. Biophys. Sin. (Shanghai) 41: 446455.

JiAng S.T., Hong G.Y., Yu M., Li N., YANG Y., LiU Y.Q. \& WeI Z.J. 2009: Characterization of the complete mitochondrial genome of the giant silkworm moth, Eriogyna pyretorum (Lepidoptera: Saturniidae). - Int. J. Biol. Sci. 5: 351-365.

Junqueira A.C., Lessinger A.C., Torres T.T., Da Silva F.R., Vettore A.L., Arruda P. \& Azeredo Espin A.M. 2004: The mitochondrial genome of the blowfly Chrysomya chloropyga (Diptera: Calliphoridae). - Gene 339: 7-15.

Kim M.I., BAeK J.Y., Kim M.J., Jeong H.C., Kim K.G., BAE C.H., HAN Y.S., JIN B.R. \& KIM I. 2009a: Complete nucleotide sequence and organization of the mitogenome of the red-spotted apollo butterfly, Parnassius bremeri (Lepidoptera: Papilionidae) and comparison with other lepidopteran insects. - Mol. Cells 28: $347-363$.
Kim S.R., Kim M.I., Hong M.Y., Kim K.Y., Kang P.D., Hwang J.S., Han Y.S., Jin B.R. \& KIM I. 2009b: The complete mitogenome sequence of the Japanese oak silkmoth, Antheraea yamamai (Lepidoptera: Saturniidae). - Mol. Biol. Rep. 36: 1871-1880.

Kim M.J., Jeong H.C., Kim S.R. \& Kim I. 2011: Complete mitochondrial genome of the nerippe fritillary butterfly, Argynnis nerippe (Lepidoptera: Nymphalidae). — Mitochondrial DNA 22: $86-88$.

KIM M.J., CHOI S.W. \& KIM I. 2013: Complete mitochondrial genome of the larch hawk moth, Sphinx morio (Lepidoptera: Sphingidae). - Mitochondrial DNA 24: 622-624.

LAFOnTAINE J.D. \& Fibiger M. 2006: Revised higher classification of the Noctuoidea (Lepidoptera). - Can. Entomol. 138: 610-635.

Lammermann K., Vogel H. \& Traut W. 2016: The mitochondrial genome of the Mediterranean flour moth, Ephestia kuehniella (Lepidoptera: Pyralidae), and identification of invading mitochondrial sequences (Numts) in the $\mathrm{W}$ chromosome. - Eur. $J$. Entomol. 113: 482-488.

Lewis D.L., Farr C.L. \& Kaguni L.S. 1995: Drosophila melanogaster mitochondrial DNA: Completion of the nucleotide sequence and evolutionary comparisons. - Insect Mol. Biol. 4: $263-278$.

Li D., Guo Y., Shao H., Tellier L.C., Wang J., Xiang Z. \& Xia Q. 2010: Genetic diversity, molecular phylogeny and selection evidence of the silkworm mitochondria implicated by complete resequencing of 41 genomes. - BMC Evol. Biol. 10: 81, 10 pp.

Li W., Zhang X., Fan Z., Yue B., Huang F., King E. \& Ran J. 2011: Structural characteristics and phylogenetic analysis of the mitochondrial genome of the sugarcane borer, Diatraea saccharalis (Lepidoptera: Crambidae). — DNA Cell Biol. 30: 3-8.

Liao F., Wang L., Wu S., Li Y.P., Zhao L., Huang G.M., Niu C.J., LIU, Y.Q. \& Li M.G. 2010: The complete mitochondrial genome of the fall webworm, Hyphantria cunea (Lepidoptera: Arctiidae). - Int. J. Biol. Sci. 6: 172-186.

Liu Y.Q., Li Y.P., PAN M.H., Dai F.Y., Zhu X.W., Lu C. \& XIANG Z.H. 2008: The complete mitochondrial genome of the Chinese oak silkmoth, Antheraea pernyi (Lepidoptera: Saturniidae). Acta Biochim. Biophys. Sin. 40: 693-703.

Liu Q.N., Zhu B.J., Dai L.S., Wei G.Q. \& Liu C.L. 2012: The complete mitochondrial genome of the wild silkworm moth, Actias selene. - Gene 505: 291-299.

Liu Q.N., Zhu B.J., DAI L.S. \& Liu C.L. 2013: The complete mitogenome of Bombyx mori strain Dazao (Lepidoptera: Bombycidae) and comparison with other lepidopteran insects. Genomics 101: 64-73.

Liu S.X., Xue D.Y., Cheng R. \& Han H.X. 2014: The complete mitogenome of Apocheima cinerarius (Lepidoptera: Geometridae: Ennominae) and comparison with that of other lepidopteran insects. - Gene 547: 136-144.

Liu Q.N., Bian D.D., Jiang S.H., Ge B.M., Zhou C.L. \& Tang B.P. 2015: Characterization of the complete mitochondrial genome of the Oriental armyworm, Mythimna separata (Lepidoptera: Noctuidae). — Eur. J. Entomol. 112: 399-408.

Liu Q.N., Zhu B.J., Dai L.S., Wang L., Qian C., Wei G.Q. \& LiU C.L. 2016: The complete mitochondrial genome of the common cutworm, Spodoptera litura (Lepidoptera: Noctuidade). - Mitochondrial DNA 27: 122-123.

Lowe T.M. \& EdDY S.R. 1997: Trnascan-Se: A program for improved detection of transfer RNA genes in genomic sequence. - Nucl. Acids Res. 25: 955-964.

Lu H.F., Su T.J., Luo A.R., Zhu C.D. \& Wu C.S. 2013: Characterization of the complete mitochondrion genome of diurnal 
moth Amata emma (Butler) (Lepidoptera: Erebidae) and its phylogenetic implications. - PloS ONE 8(9): e72410, 14 pp.

Pan M., Yu Q., Xia Y., Dai F., Liu Y., Lu C., Zhang Z. \& Xiang Z. 2008: Characterization of mitochondrial genome of Chinese wild mulberry silkworm, Bomyx mandarina (Lepidoptera: Bombycidae). - Sci. China (C, Life Sci.) 51: 693-701.

Salvato P., Simonato M., Battisti A. \& Negrisolo E. 2008: The complete mitochondrial genome of the bag-shelter moth Ochrogaster lunifer (Lepidoptera, Notodontidae). - BMC Genomics 9: 331, 15 pp.

Shadel G.S. \& Clayton D.A. 1993: Mitochondrial transcription initiation. Variation and conservation. - J. Biol. Chem. 268 16083-16086.

Sun Q.Q., Sun X.Y., Wang X.C., Gai Y.H., Hu J., Zhu C.D. \& HAO J.S. 2012: Complete sequence of the mitochondrial genome of the Japanese buff-tip moth, Phalera flavescens (Lepidoptera: Notodontidae). — Genetics Mol. Res. 11: 4213-4225.

TAANMAN J.W. 1999: The mitochondrial genome: Structure, transcription, translation and replication. - Biochim. Biophys. Acta 1410: 103-123.

Tamura K., Peterson D., Peterson N., Stecher G., Nei M. \& Kumar S. 2011: Mega5: Molecular evolutionary genetics analysis using maximum likelihood, evolutionary distance, and maximum parsimony methods. - Mol. Biol. Evol. 28: 2731-2739.

Thompson J.D., Gibson T.J., Plewniak F., Jeanmougin F. \& HigGINS D.G. 1997: The clustal_X windows interface: Flexible strategies for multiple sequence alignment aided by quality analysis tools. - Nucl. Acids Res. 25: 4876-4882.

Wei S.J., Shi B.C., Gong Y.J., Li Q. \& Chen X.X. 2013: Characterization of the mitochondrial genome of the diamondback moth Plutella xylostella (Lepidoptera: Plutellidae) and phylogenetic analysis of advanced moths and butterflies. - DNA Cell Biol. 32: 173-187.

Wolstenholme D.R. 1992: Animal mitochondrial DNA: Structure and evolution. - Int. Rev. Cytol. 141: 173-216.

Wu L.W., Lees D.C., Yen S.H., Lu C.C. \& Hsu Y.F. 2010: The complete mitochondrial genome of the near-threatened swallowtail, Agehana maraho (Lepidoptera: Papilionidae): Evaluating sequence variability and suitable markers for conservation genetic studies. - Entomol. News 121: 267-280.

Wu Y.P., Zhao J.L., Su T.J., Li J., Yu F., Chesters D., Fan R.J., Chen M.C., Wu C.S. \& Zhu C.D. 2012: The complete mitochondrial genome of Leucoptera malifoliella Costa (Lepidoptera: Lyonetiidae). — DNA Cell Biol. 31: 1508-1522.

Wu Q.L., CUI W.X. \& WEI S.J. 2015: Characterization of the complete mitochondrial genome of the black cutworm Agrotis ipsilon (Lepidoptera: Noctuidae). - Mitochondrial DNA 26: 139-140.
Xu Y.M., Chen S.C., Wang X.Q., Peng P. \& Li P.W. 2015: The complete mitogenome of Jankowskia athleta (Lepidoptera: Geometridae). - Mitochondrial DNA 27: 3035-3036.

YAng L., Wei Z.J., Hong G.Y., Jiang S.T. \& Wen L.P. 2009: The complete nucleotide sequence of the mitochondrial genome of Phthonandria atrilineata (Lepidoptera: Geometridae). - Mol. Biol. Rep. 36: 1441-1449.

YANG X.S., XuE D.Y. \& HAN H.X. 2013: The complete mitochondrial genome of Biston panterinaria (Lepidoptera: Geometridae), with phylogenetic utility of mitochondrial genome in the Lepidoptera. - Gene 515: 349-358.

Yang X.S., Cameron S.L., Lees D.C., Xue D.Y. \& Han H.X. 2015: A mitochondrial genome phylogeny of owlet moths (Lepidoptera: Noctuoidea), and examination of the utility of mitochondrial genomes for lepidopteran phylogenetics. Mol. Phylogenet. Evol. 85: 230-237.

Yukuhiro K., Sezutsu H., Itoh M., Shimizu K. \& Banno Y. 2002: Significant levels of sequence divergence and gene rearrangements have occurred between the mitochondrial genomes of the wild mulberry silkmoth, Bombyx mandarina, and its close relative, the domesticated silkmoth, Bombyx mori. - Mol. Biol. Evol. 19: 1385-1389.

Zahiri R., Kitching I.J., Lafontaine J.D., Mutanen M., Kaila L., Holloway J.D. \& WAHLBerg N. 2011: A new molecular phylogeny offers hope for a stable family level classification of the Noctuoidea (Lepidoptera). — Zool. Scr. 40: 158-173.

Zahiri R., Holloway J.D., Kitching I.J., Lafontaine J.D., MuTANEN M. \& WAHLBERG N. 2012: Molecular phylogenetics of Erebidae (Lepidoptera, Noctuoidea). - Syst. Entomol. 37: $102-124$.

Zaspel J.M., Weller S.J., Wardwell C.T., Zahiri R. \& WahlBERG N. 2014: Phylogeny and evolution of pharmacophagy in tiger moths (Lepidoptera: Erebidae: Arctiinae). - PloS ONE 9(7): e101975, $10 \mathrm{pp}$.

ZHANG Z.Q. 2013: Animal biodiversity: An outline of higherlevel classification and survey of taxonomic richness (addenda 2013). - Zootaxa 3703: 1-82.

Zhang M., Nie X.P., CaO T.W., Wang J.P., Li T., Zhang X.N., Guo Y.P., MA E.B. \& ZHONG Y. 2012: The complete mitochondrial genome of the butterfly Apatura metis (Lepidoptera: Nymphalidae). - Mol. Biol. Rep. 39: 6529-6536.

Zhao J.L., Zhang Y.Y., Luo A.R., Jiang G.F., Cameron S.L. \& ZHU C.D. 2011: The complete mitochondrial genome of Spilonota lechriaspis Meyrick (Lepidoptera: Tortricidae). - Mol. Biol. Rep. 38: 3757-3764.

Zhu B.J., LiU Q.N., Dai L.S., WANG L., Sun Y., Lin K.Z., WeI G.Q. \& LiU C.L. 2013: Characterization of the complete mitochondrial genome of Diaphania pyloalis (Lepidoptera: Pyralididae). - Gene 527: 283-291.

Received August 28, 2016; revised and accepted October 31, 2016 Published online December 5, 2016 